\title{
Festschrift vir Heilna du Plooy The Heilna du Plooy Festschrift
}

Author:
Hein Viljoen ${ }^{1}$
Affiliation:
${ }^{1}$ School of Languages,
North-West University,
Potchefstroom Campus,
South Africa
Correspondence to:
Hein Viljoen
Email:
hein.viljoen@nwu.ac.za
Postal address:
Private Bag X6001,
Potchefstroom 2520,
South Africa
How to cite this article:
Viljoen, H., 2012, 'Festschrift
vir Heilna du Plooy/The
Heilna du Plooy Festschrift',
Literator 33(2), Art. \#411,
3 pages. http://dx.doi.org/
10.4102/lit.v33i2.411

C 2012. The Authors. Licensee: AOSIS OpenJournals. This work is licensed under the Creative Commons Attribution License.

\section{Voorwoord}

Hierdie nommer van Literator word opgedra aan Heilna du Plooy wat aan die einde van 2012 aftree as hoogleraar in Afrikaans en Nederlands en literêre teorie. In haar loopbaan van 35 jaar het Heilna du Plooy haar onderskei as narratoloog, navorser, kritikus en populariseerder van die letterkunde.

Heilna du Plooy is 'n skilder en digter in eie reg. Sy het reeds twee poësiebundels naas talle gedigte en kortverhale in tydskrifte gepubliseer. Sy is ook baie aktief as openbare spreker en populariseerder van die letterkunde en die skryfkuns by werkwinkels, leeskringe en seminare. Daarby is sy ook vertaler, onder andere, van Willem van Toorn se Het stuwmeer (2009a) in voortreflike Afrikaans. Die vertaling het saam met 'n essay van haar in Tirade verskyn.

As kritikus bly haar oordeel in aanvraag op keurkomitees vir literêre pryse soos die M-Net prys en die W.A. Hofmeyr-prys. Sy dien nog steeds op die Letterkundige Kommissie van die Akademie. Ander spesiale opdragte sluit in haar medewerking aan T.T. Cloete se Literêre terme en teorieë en aan die Tussenkerklike Psalmberymingskommissie (1995-2003). Tans sit sy hierdie voortreflike werk voort as lid van die Letterkundige Advieskomitee en intravertaler vir die nuwe Afrikaanse Bybelvertaling.

Sy is lid van internasionale verenigings soos die Society for the Study of Narrative Literature en die Internationale Vereniging voor Neerlandistiek. In vakverenigings, die organisasie van kongresse en in die redaksies van vaktydskrifte soos Literator, Tydskrif vir Nederlands en Afrikaans en Stilet speel sy 'n leidende rol. Sy was baie aktief in die bestuur van die Afrikaanse Letterkundevereniging, ook as voorsitter, en het van 1990 tot 1998 gedien op die adviesraad van die Nederlandse tydskrif Woordwerk, 'n Christelike literêre tydskrif. Daarby is sy onlangs verkies tot vise-president van die Raad van Trustees van die Greenwich School of Theology in Londen.

\section{Preface}

This issue of Literator is dedicated to Heilna du Plooy who retires at the end of 2012 as professor of Afrikaans and Dutch literature and literary theory. In a career spanning 35 years she distinguished herself as narratologist, researcher, critic, and apologist for literature.

Heilna du Plooy is an artist and poet in her own right, with two poetry collections published besides numerous other poems and short stories in journals. She is very active as a public speaker and apologist for literature and creative writing at reading circles and seminars. She also is a literary translator, her latest translation begin an excellent Afrikaans version of Willem van Toorn's cycle of poems Het stuwmeer (The reservoir 2009a) into Afrikaans. This was published with one of her own essays in the Dutch journal Tirade.

As critic her judgement remains in demand on the juries of literary prizes, like the M-Net Prize and the W.A. Hofmeyr Prize. She still serves on the Literary Committee of the SA Akademie vir Wetenskap en Kuns. Other special assignments include her contribution to T.T. Cloete's Literêre terme en teorieë (Literary terms and theories) and her work on the interdenominational committee for the versification of the Psalms (1995-2003). Currently she is continuing this excellent work as member of the Literary Advisory Committee and literary translator of the new Afrikaans Bible translation.

She is a member of international associations such as the Society for the Study of Narrative Literature and the International Society for Dutch studies. She played a leading role in academic societies, in the organisation of conferences and on the editorial boards of journals like Literator, Tydskrif vir Nederlands en Afrikaans and Stilet. In particular, she was very active on the executive of Afrikaans Literature Association. From 1990 to 1998 she served on the advisory board of the Dutch journal Woordwerk, a Christian literary magazine. Recently she was elected vicepresident of the Board of Trustees of the Greenwich School of Theology in London. 
Dit is egter as dosent en navorser dat sy die grootste skeppende bydrae gelewer het tot die uitbou van die literatuurwetenskap, sowel teoreties as op die gebied van die Afrikaanse en moderne Nederlandse letterkunde. Hiervan getuig haar talle publikasies: boeke soos Verhaalteorie in die twintigste eeu, talle hoofstukke in boeke en artikels in geakkrediteerde tydskrifte, binnelands en internasionaal. Haar publikasies is telkens deeglik en oorwoë. Sy het ' $n$ fyn aanvoeling vir die letterkunde en verwoord haar insigte uitstekend. Haar kreatiewe aanslag blyk reeds uit die titels wat sy kies: 'Intertekstualiteit as simbiotiese saambestaan: Twee naamgenote en 'n belese engel' (1998), 'Taking a line for a walk - poetic contour drawings and contoured poems.' In die T.T. Cloete-erelesing $(2009 b, 2009 c)$ het sy getoon dat sy skerp teoretiese insigte in ikonisiteit kan gebruik om Cloete se werk te deurskou en tegelyk haar gehoor kan meevoer. Vir dié lesing het sy ook 'n kreatiewe titel bedink, 'Die deurskynende kelk. Oor vorm en inhoud in die poësie'.

As studieleier en promotor van $23 \mathrm{MA}$ - en $12 \mathrm{PhD}$-studente asook eksterne eksaminator van talle verhandelings en proefskrifte lewer sy ook 'n enorme bydrae. Besondere studies wat die afgelope tyd onder haar leiding voltooi is, sluit in Jean Lombard se studie van Waterslangverhale in Afrikaans, M. Taljard se studie van Kleur kom nooit alleen nie en A.P. Roux se studie van Memorandum: 'n verhaal met skilderye. In die Navorsingseenheid: Tale en literatuur in die Suid-Afrikaanse konteks speel sy 'n leidende en inspirerende rol in die letterkundenavorsing.

Ook internasionaal het Heilna du Plooy 'n groot bydrae tot die studie van die Afrikaanse letterkunde gelewer. Behalwe haar aktiewe deelname aan nasionale kongresse het sy meer as 30 lesings by internasionale kongresse gelewer, asook 'n reeks gaslesings in die buiteland, onder andere, by die Seminarie Afrikaans in Diepenbeeck en die program vir Afrikaans aan die Universiteit van Antwerpen. Onlangse referate by internasionale kongresse sluit in 'Iconicity in narrative texts: Words, like shells, are signs as well as things' by die kongres oor Iconicity in Language and Literature in Toronto en 'Coherentie in vier cycli van Willem van Toorn' by die Achttiende colloquium neerlandicum in Antwerpen.

Vanaf 2004 tot 2011 was Heilna die leier van die interessante projek Vers en verhaal: narratiewe binding in poëtiese tekste, waaraan kollegas uit Suid-Afrika, Nederland en België saamgewerk het. Dit uitgeloop op spesiale uitgawes van Literator en Stilet waarin die verhalende fasette van die poësie deeglik ontleed is. Tans werk sy saam met Peter Hühn van Hamburg en ander kollegas aan 'n boek oor Eventfulness in Lyric Poetry.

In haar veelfasettige loopbaan as navorser, akademikus, dosent, digter en bedrewe spreker het Heilna du Plooy 'n grondliggende bydrae gelewer tot die ontwikkeling van die literatuurwetenskap en die studie en onderrig van die Afrikaanse en die moderne Nederlandse letterkunde. Persoonlik werk ons al saam sedert 1987 toe sy in die destydse
It is as lecturer and researcher that Heilna made her biggest creative contribution to the study of literature, both theoretically and in the field of Afrikaans and modern Dutch literature. Her many publications are eloquent testimony to this: books like Verhaalteorie in die twintigste eeu (Narrative theory in the twentieth century), numerous book chapters and articles in accredited journals, both in South Africa and internationally. Her publications are always thoughtful and thorough. She has a refined literary sensibility and can articulate her insights cogently. Her creative approach already emerges from her essay titles: 'Intertextuality as symbiotic coexistence: Two namesakes and a well-read angel' (1998), 'Taking a line for a walk - poetic contour drawings and contoured poems.' In her T.T. Cloete Memorial Lecture $(2009 b, 2009 c)$ she demonstrated how acute theoretical insights into iconicity can illuminate Cloete's poetry, enthralling her audience at the same time. For this lecture she also devised a creative title, 'The transparent chalice: On form and content in poetry.'

As supervisor and promoter of $22 \mathrm{MA}$ and $12 \mathrm{PhD}$ students as well as external examiner of numerous dissertations and theses Heilna has made, and continues to make a huge contribution. Specific recently completed studies include Jean Lombard's study of water snake stories in Afrikaans, M. Taljard's study of Krog's Kleur kom nooit alleen nie (Colour never comes on its own), and A.P. Roux's study of Memorandum: 'n verhaal met skilderye (Memorandum: A narrative with paintings). In the Research Unit: Languages and Literature in the South African context she plays a leading and inspiring role.

Internationally Heilna du Plooy also made a significant contribution to the study of Afrikaans literature. In addition to her active participation in national congresses she presented more than 30 papers at international conferences and also gave a series of guest lectures abroad, among others at the Afrikaans Seminary in Diepenbeeck and the programme for Afrikaans at the University of Antwerp. Recent papers at international conferences include 'Iconicity in narrative texts: Words, like shells, are signs as well as things' at the Toronto Congress on Iconicity in Language and Literature and 'Coherence in four cycles of Willem van Toorn' at the Eighteenth Colloquium Neerlandicum in Antwerp.

From 2004 to 2011 Heilna was the leader of a project on narrative coherence in lyrical poetry, in which colleagues from South Africa and the Netherlands and Belgium particpated. This led to special issues of Literator and Stilet in which the narrative aspects of poetry were analysed thoroughly and thoughtfully. At present she is collaborating with Peter Hühn from Hamburg and other colleagues on a book entitled Eventfulness in Lyric Poetry.

In her multi-faceted career as a researcher, scholar, lecturer, poet and skilled literary apologist Heilna du Plooy has made a fundamental contribution to the development of literary studies and the study and teaching of Afrikaans and modern Dutch literature. Personally I have worked with Heilna since 
departement Algemene Taal- en Literatuurwetenskap begin klasgee het. In dié tyd het ek haar leer ken en waardeer as 'n lojale kollega, innemend en gebalanseerd, en as ' $n$ baie getroue en produktiewe medewerker aan navorsingprojekte. Met hierdie spesiale nommer van Literator huldig ons as haar vriende, kollegas en studente haar in al hierdie hoedanighede.

\section{Literatuurverwysings}

Du Plooy, H., 1986, Verhaalteorie in die twintigste eeu, Butterworth, Durban.

Du Plooy, H., 1998, 'Intertekstualiteit as simbiotiese saambestaan: Twee naamgenote en 'n belese engel', Literator 9(3), 5-28.

Du Plooy, H., 2009a, 'Die huis onder die water: 'n Essay, asook die vertaling van "Het stuwmeer van Willem van Toorn"', Tirade 53(2).

Du Plooy, H., 2009b, 'Taking a line for a walk: Poetic contour drawings and contoured poems', in R. Johl, M.P. Beukes, O.C.M. Fischer, C. Ljungberg \& C.J. Conradie (eds.), Sinergy. Iconicity in Language and Literature 9, pp. 157-178, John Benjamins, Amsterdam/Philadelphia.

Du Plooy, H., 2009c, 'Die deurskynende kelk: Oor vorm en inhoud in die poësie', Tydskrif vir Geesteswetenskappe 49(3), 596-621.

Van Vliet, E., 1998, 'n Pleidooi vir die poësie, vert. H. du Plooy, Protea Poësie, Pretoria.
1987, when she started teaching in the then department of Linguistics and Literary Theory. Since then I have come to know her well and appreciate her highly as loyal colleague with warmth and poise and as a productive collaborator in research projects. With this special issue of Literator we as friends, colleagues and students honour her in all these capacities.

\section{References}

Du Plooy, H., 1986, Verhaalteorie in die twintigste eeu, Butterworth, Durban.

Du Plooy, H., 1998, 'Intertekstualiteit as simbiotiese saambestaan: Twee naamgenote en ' $n$ belese engel', Literator 9(3), 5-28.

Du Plooy, H., 2009a, 'Die huis onder die water: 'n Essay, asook die vertaling van “Het stuwmeer van Willem van Toorn"', Tirade 53(2).

Du Plooy, H., 2009b, 'Taking a line for a walk: Poetic contour drawings and contoured poems', R. Johl, M.P. Beukes, O.C.M. Fischer, C. Ljungberg \& C.J. Conradie (eds.), Sinergy. Iconicity in Language and Literature 9, pp. 157-178, John Benjamins, Amsterdam/Philadelphia.

Du Plooy, H., 2009c, 'Die deurskynende kelk: Oor vorm en inhoud in die poësie', Tydskrif vir Geesteswetenskappe 49(3), 596-621.

Van Vliet, E., 1998, 'n Pleidooi vir die poësie, vert. H. du Plooy, Protea Poësie, Pretoria. 